\section{Managerial aspects of operating performance groups in agriculture}

\author{
György Szabados \\ University of Debrecen, \\ Faculty of Agricultural Economics and Rural Development, \\ Department of Management and Labour Sciences, Debrecen \\ szabados@agr.unideb.hu
}

\section{SUMMARY}

Although we often witness groups, teams operating on various fields of life, we have not learnt much about various types of groups and teams in the agricultural sector, little is know about operational rules, internal properties, even less the managerial aspects. The Department of Management of University of Debrecen has been conducting research in this field for many years. In the framework of the research program, I have surveyed the managerial approach to identify main and typical characteristics of performance groups.

During my researches I was determined to find out more about internal rules, relations and characteristics.

Keywords: agricultur, management, group operation, leadership

\section{INTRODUCTION}

In the last years we often witness groups, teams operating on various fields of life. Although researching them seems a novel phenomenon in Hungary, business sector increasingly apply the rules, the characteristics of operation, we often heard about team building trainings, which became mainly widespread in the 90s (although we may find detailed descriptions in issues of Industry Economic Institute about teambuilding in state companies in the $80 \mathrm{~s}$ ). In many cases, we cannot sense this organization unit at work, still we assume its presence owing to its signs (norms, position, and polarization), and most of them are typical of the phenomena (Dienesné, 2003). Moreover, only few scientific researches indicate the presence of relation, network of people, instead, single individuals are examined for human decisions, attitude, and behavior. These factors have an effect on each other, and form different rules, connections regarding operation. Our accession to the EU accelerated the intentions to cooperate, new challenges, tasks also emphasized the importance of social skills on managerial level (Juhász, 2004). Increased expectations may be experienced considering organizational needs, higher performance, efficiency and effectiveness, quality requirements (Gályász, 2006), which may be met by tight cooperation. Examining the agricultural sector I conceived, that seasonality (and its direct sequent, the changing, dynamic work structure), professional tasks and challenges justify the reason for the research; mainly managers need to learn more about the human aspects of it.

Examining the managerial aspect of group operation, I edited a questionnaire regarding professional literatures, suggestions. Considering the results of preliminary surveys it was revised many times, and finally survey was taken by attendants. Considering the diverse fields and approaches of the subject, I regarded the managerial point of view, which considers the area in its process. Managerial perception of group work performance seemed to be important to consider since professional literatures have a distinct approach of the subject. Klein (1998) treated team as a largely cooperating group, and other authors (Larson and Lafasto, 1989; Blanchard et al., 1990; Gállos, 1990; Schermerhorn et al., 1995) also defined terms for teams. My examinations required a united approach, so I treated them as one due to the coherence of the examinations. Questions of the survey reflect process approach, they range from the creation of groups (formation aspect, formation method), to the internal signs of operation (membership values, norms, status, role, cohesion, polarization, organizational task and position), and professional approach ends with eligibility and efficiency/effectiveness reasons (Figure 1).

The questionnaire included basic, corporate data collector section, interviewee data section, and the professional interview, where 15 questions had to be ranked on a scale from 1-5. Results reflect the data of 477 interviews. Reliability of the questionnaire was tested by examination of internal consistency, the Cronbach $£$ value reflects a high reliability $(0.938)$.

Descriptive statistics examinations were supplemented by main component analysis, I worked with 104 questions and created 43 variables (33 main components and missing values), cluster analysis contributed to the understanding of depth of processes. Sample reflects the opinion of manager majority of agricultural and food industrial organizations, including $71 \%$ corporations $(92 \%$ of them has more than 10 employees). $77 \%$ of managers had a higher graduation, $80 \%$ is middle aged, the distribution of bottom, middle and top managers are 33, 46, 21.

Principal part of the research focused on the attitude of managers for the application of common work performance. It was considered useful by $96 \%$ of the interviewees, and $99 \%$ of managers had experience in working together. For top, middle and lower level managers, the results coincide with each other. This means common work performance appears to be more efficient and effective this way.

Considering formation factors, technical point of views, work tasks play an important role in the creation of groups. Considering the methods of establishment, the same factors dominate. Drastic 
methods of group creation, such as enforcement and power, were qualified with lower values.

Figure 1: The managerial process of group operation

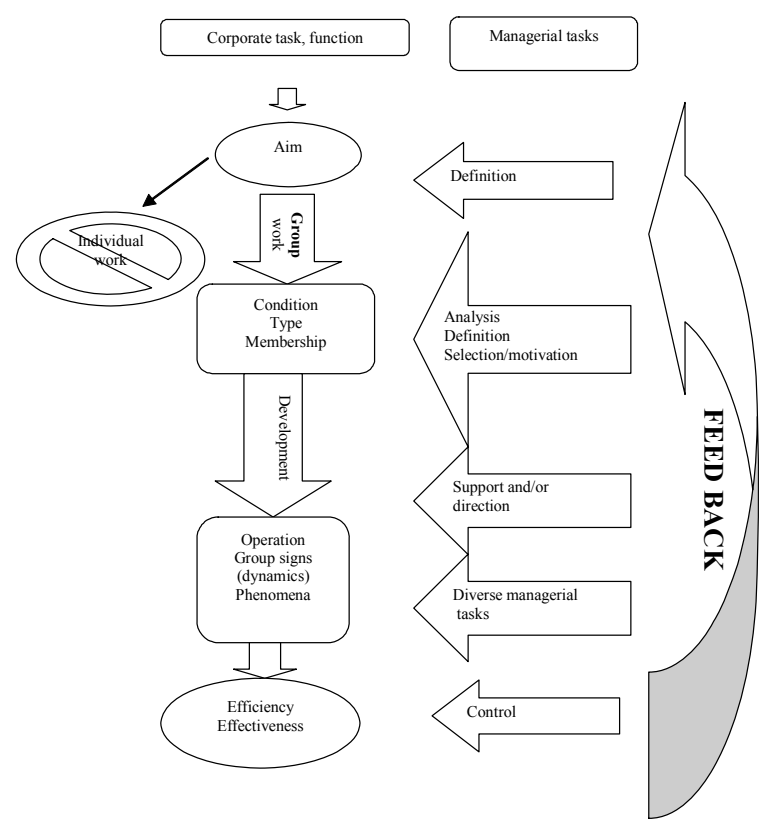

Source: Private editing, 2007.

Examining the internal relations inside, I treated 3 factors (benefits, drawbacks and other membership related aspects) together. Of the benefits, more efficient task realization, of the drawbacks, opposition and strict norms were emphasized. Regarding membership relations, benefits (efficiency, acknowledgement and support) were empathized, and drawbacks (restricting and limiting factors) were neglected.

Status and role examinations were treated together, since first defines horizontal, the other defines vertical position. State is mainly determined by technical competence and performance; most important was the monitor-evaluator role. Findings suggest that of the group norms, formal organization functions and honors were emphasized.
Cohesion and polarization were treated together. Cohesion is mainly determined by the agreement in principles, and polarization mainly seems to be the result of personality related factors.

Results of success and failure examination suggest that factors posses a greater role in the success compared to the failure. The same factor (reachable goals and efficiency) dominates in both cases.

Regarding main component analysis, I have calculated with 104 questions, and 43 variables (33 main and 10 independent variables) were created. Variables were examined by sex, age, graduation, position, operation form and number of employees. I applied parametric variance analysis to find differences in the samples, and non-parametric tests ware carried out for the missing values.

Analyzing the sex related factors of respondents, I have found that women posses a larger importance for the formal functional being of the group operation. Missing value analysis revealed that authority factors (leadership, enforcement, and power) seem to be more important for and typical of men.

Considering age related examinations, five age groups were defined. Examinations revealed that significant differences mainly appeared in the case of relatively younger and older respondents and mainly financial and prestige, correlation and efficiency reasons seemed to be more determining. Analysis of missing values indicated that importance of leadership role increases with age.

Graduation related examinations revealed that technical aspects of formation were mainly important for the ones with higher graduation, its importance decreases with the lower graduation. Importance of internal group factors (norms, cohesion, and appeal) also rises with graduation; with means these respondents have a higher and more thorough view of group operation. Leadership role is getting more important with the graduation, too. Other roles (company worker, resource investigator, shaper and monitor-evaluator) and the position of power, autocracy as a determining group formatting factor will get more emphasized with age, too.

No significant differences were found considering organization form examinations.

The analysis of significant differences in managerial tasks by employee categories

\begin{tabular}{|l|c|c|c|c|c|c|}
\hline \multicolumn{1}{|c|}{$\begin{array}{c}\text { Employee } \\
\text { categories }\end{array}$} & Method & Benefit & Norms & Polarization & Membership & Efficiency \\
\hline $\mathbf{2 5 0}$ & $\begin{array}{c}\text { Common } \\
\text { orientation }\end{array}$ & $\begin{array}{c}\text { Technical } \\
\text { reasons }\end{array}$ & Atmos-phere & $\begin{array}{c}\text { Position related } \\
\text { factors }\end{array}$ & Appeal & $\begin{array}{c}\text { Norm related } \\
\text { factors }\end{array}$ \\
\hline $\mathbf{5 0 - 2 5 0}$ & $\begin{array}{c}\text { Technical } \\
\text { reason }\end{array}$ & $\begin{array}{c}\text { Financial } \\
\text { reasons }\end{array}$ & & Task share factors & Group restraint & \\
\hline $\mathbf{1 0 - 5 0}$ & & $\begin{array}{c}\text { Financial } \\
\text { reasons }\end{array}$ & & & Efficiency factors & \\
\hline $\mathbf{- 1 0}$ & & & & & & \\
\hline
\end{tabular}

Source: Private editing, 2007. 
4 categories were distinct at employee number examinations (1-9 micro, 10-50 small, 51-249 medium, 250- large companies, depending on the number of employees). Many significant differences $(\mathrm{p}<0.05)$ were revealed, results are illustrated in Table 1.

Results show that analysis of formation methods, membership benefits, polarization reasons and membership related questions revealed differences by employee categories. Group members of larger companies mainly join for technical reasons, while membership seems to be attractive for financial reason for members of smaller companies. Companies also differ in membership related questions, groups of larger companies have the benefit of appeal and attractiveness, middle level company groups seem to limit the membership and groups of smaller companies seem to be more efficient for its members.

Results of main component analysis were supplemented by cluster analysis. Distinctive characteristics of the clusters were the following:

1. Middle age managers of co-operatives and other organizations.

2. Elder top managers of corporations.

3. Young, lower and middle level managers of corporations and public companies.

4. Elder, lower and middle level managers of corporations and public companies.

Research results are illustrated in Table 2:

Results of cluster analysis

\begin{tabular}{|c|c|c|c|c|c|c|c|}
\hline & \multicolumn{2}{|c|}{ Formation } & \multirow{2}{*}{$\begin{array}{l}\text { Benefits } \\
\text { Finance }\end{array}$} & \multirow{2}{*}{$\begin{array}{c}\text { Polarization } \\
\text { Diverse } \\
\text { value } \\
\end{array}$} & \multicolumn{2}{|c|}{ Membership } & \multirow{2}{*}{$\begin{array}{c}\text { Failure } \\
\text { Norm } \\
\text { relation } \\
\end{array}$} \\
\hline $\begin{array}{l}\text { Factors/ } \\
\text { Clusters }\end{array}$ & $\begin{array}{c}\text { Technical } \\
\text { factor }\end{array}$ & Info & & & $\begin{array}{l}\text { Group } \\
\text { appeal }\end{array}$ & Restraint & \\
\hline 1. Cluster & - & + & - & $\sim$ & + & $\sim$ & + \\
\hline 2. Cluster & + & - & $\sim$ & $\sim$ & $\sim$ & - & - \\
\hline 3. Cluster & + & - & + & - & - & $\sim$ & $\sim$ \\
\hline 4. Cluster & $\sim$ & $\sim$ & $\sim$ & + & $\sim$ & + & + \\
\hline
\end{tabular}

Source: Private editing, 2007. Legends: (+)-important, $(\sim)$ average, (-) less important

Based on the result I believe that financial values of benefits seem to be important for the younger, lower and middle level managers of corporations and public companies. The effect of diverse value orientation in polarization does not seem to be a determinant factor for them. Group appeal has a little effect on membership by them.

Restricts are largely ignored by the elder, top manager of small companies. They seem to be rather sensitive for limitations.

Failure does not have a lot to do with norm related factors by elder top managers of corporations.

Analysis of missing values revealed judgment of chairman/ leadership role.

Of the roles indicated, the role of leadership (chairman) has a high importance for the 2. cluster, queerly its attitude changes with age and position. Results revealed that it probably seems to be a special position, which varies with age, position, graduation (Figure 2).

Observing the differences between the clusters, I found that leadership intention is not typical of young, lower and middle level managers of corporations and public companies, and its is mostly valid for elder top managers of corporations, moreover it is related to the managerial position. Intention is probably also connected to age, position, and graduation, it is justified by the results of main component analysis, too, which revealed the increased leadership attention by age.

Age related examinations indicated the positive relation between age and leadership, which is now validated.

\section{CONSEQUENCES}

Although the operation of groups seem to be an usual and general phenomena in agricultural production, only little is known about specialties in the field of agriculture, even less examinations have been carried out so far in this subject. Despite numerous professional literature findings, operation of groups still seems to be an active managerial function. Agricultural managers seem to have expertise related to the groups operation; they believe it is a proper leverage for achieving corporate goals. Establishment and coordination of operational conditions are based on organizational function, and it seems to be valid and dominating for the time of operation, too. The formation is mainly technical related. Of the benefits of membership, more efficient task realization, of the drawbacks opposition and strict norms were emphasized. Regarding membership relations, benefits were emphasized, and drawbacks were neglected. Norm examinations suggest that of the group norms, formal organizational functions were emphasized. Results of success and failure examination suggest that factors posses a greater role in the success compared to the failure. The same factors (reachable goals and efficiency) dominate in both cases. Results of main component and cluster analysis revealed many differences, of which differences in leadership intentions seems notable.

Results indicate that numerous conditions must be considered during operation. Although other factors are still need to be examined, I believe results may contribute to the better coordination, operation and understanding of performance group. 
Figure 2: Changes in leadership intentions by different factors
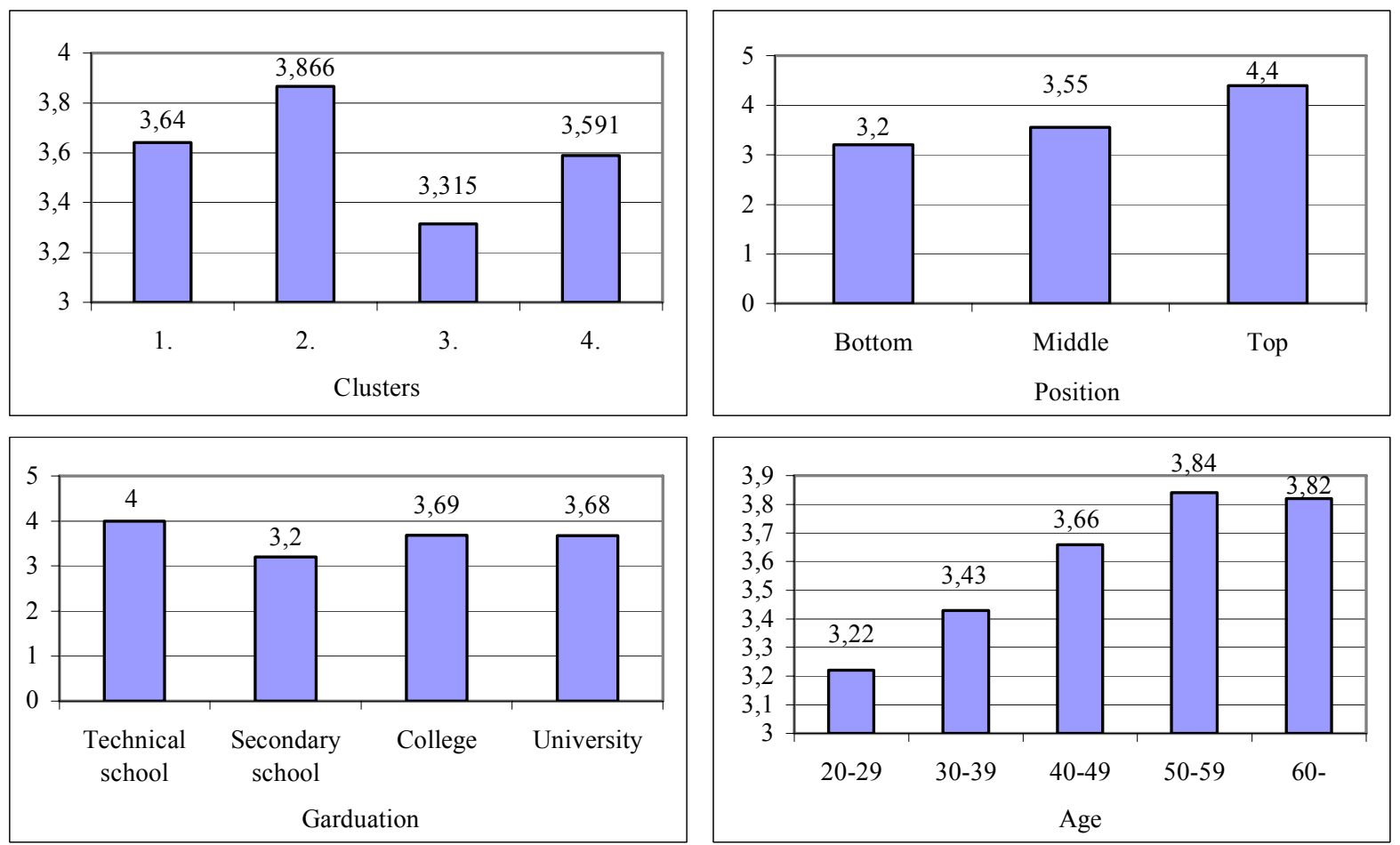

Source: Private examinations, 2007.

\section{REFERENCES}

Blanchard, K.-Carew, D.-Parisi, E. (1999): Az egyperces menedzser csapatot épít. Bagolyvár Kiadó, Budapest

Dienesné, K. E. (2003): Csoportok a szervezetben. In: Vezetéspszichológiai ismeretek. Szerk. Dienesné, K. E.Berde, Cs. Campus Kiadó, Debrecen

Gállos, Zs. (1990): Szervezés - Vezetés. A szervezési ismeretek alapjai. Szöveggyüjtemény. Államigazgatási Főiskola Nyomdája

Gályász, J. (2006): Minőséget benchmarking-gal a zöldséggyümölcs ágazatban. A XXXI. Óvári Tudományos Konferencia CD kiadványa, Mosonmagyaróvár
Juhász, P. (2004): Túlterheltek a magyar menedzserek? Világgazdaság

Klein, S. (1998): Kell egy csapat. Előszó. In: A team avagy az együttmüködő csoport. Szerk: Belbin, M. SHL Hungary Kft, Budapest

Larson, C. E.-Lafasto, F. M. J. (1989): Teamwork: What must go right, what can go wrong. Newberry Park, Sage Publications, CA

Schermerhorn, J. R.-Hunt, J. G.-Osborn, R. N. (1995): Basic Organisational Behavior, Wiley, New York 